\title{
Karin Ellen Von Smigay (1948-2011)
}

Em 12 de fevereiro de 201 1, faleceu em Belo Horizonte Karin Ellen Von Smigay.

Seu corpo foi cremado e suas cinzas encaminhadas para a cidade de Tiradentes, onde celebrou-se ritual de despedida em sua Pousada d'Oleo de Guignard, conforme seu desejo.

Karin destacou-se na militância do movimento feminista brasileiro, em Minas Gerais, em plena época da ditadura militar no país. Professora titular aposentada do Departamento de Psicologia da UFMG, Karin era Doutora em Psicologia Social, reconhecida por seus trabalhos em torno das violências de gênero. Feminista convicta, auxiliou na formação de várias gerações de militantes e pesquisadores, deixando sua marca de delicadeza e cuidado para com o outro em tudo que realizava.

Para todas/os nós que tivemos a oportunidade de conviver com ela, ficam a saudade e o exemplo de coragem, dignidade e lealdade que caracterizou sua vida pessoal e suas atividades profissionais. 